\title{
Iron Contents of Different Colonial Types of Neisseria gonorrhoeae
}

\author{
By TOLU O. ODUGBEMI \\ Department of Medical Microbiology, \\ University of Sheffield Medical School, \\ Beech Hill Road, Sheffield S10 $2 R X$ \\ AND BRIAN DEAN \\ Department of Biochemistry, University of Sheffield, \\ Sheffield SIO $2 T N$
}

(Received 13 July 1977; revised 26 September 1977)

INTRODUCTION

Four characteristic colonial types of Neisseria gonorrhoeae were described by Kellogg et al. (1963, 1968), of which types I and 2 were virulent in human volunteers whereas types 3 and 4 appeared to be laboratory variants and avirulent. In the course of studies on Kellogg's types, Jephcott \& Reyn (197I) reported a fifth type. This colonial type 5 was found in about $\mathbf{I} \%$ of cultures of human cervical and urethral specimens but its pathogenicity has not been established (Brown \& Kraus, 1974). Differences between gonococcal colonial types include possession of pili by types $\mathrm{I}$ and 2 but not by the other types (Jephcott, Reyn \& Birch-Andersen, I97I; Swanson, Kraus \& Gotschlich, I97I). Recently, Walstad, Guymon \& Sparling (1977) reported that type 3 and dark-coloured variants of types $I$ and 2 had larger amounts of outer membrane protein than light-coloured variants of types $I$ and 2, and light-coloured colonial type 4.

Bullen, Rogers \& Griffiths (1974) drew attention to the importance of iron metabolism in the pathogenicity of some micro-organisms. Although iron is essential for the growth of gonococci, its possible role in pathogenicity has not been studied. Edwards \& Seamer (I960) determined the iron content of Corynebacterium diphtheriae and showed that there was a critical optimum iron content for maximum toxin production. We have undertaken the present study to determine the iron content of the various Kellogg colonial types of gonoccci believing there may be a similar correlation between iron levels and pathogenicity.

\section{METHODS}

Strains. The strains of gonococci studied were: F62 (originally isolated in Kellogg's laboratory) from which types I, 2, 3 and 4 were derived [these were used freshly subcultured from storage in liquid nitrogen $\left(-I 20^{\circ} \mathrm{C}\right)$ ]; types I and 4 of $\mathrm{F} 62$ (ANM) [these were the same types except that they had already been passaged several times in the basic liquid medium (ANM) of Hafiz \& McEntegart (1976)]; freshly isolated strains from patients attending the Special Clinic at the Royal Infirmary, Sheffield, designated $\mathrm{GC}_{33} 8$ (types I, 2, 3 and 4), GC4I (types I, 2, 3 and 4) and GCII3 (types 4 and 5).

Growth and preparation of dried organisms. All the strains were grown on GC agar (Difco) plus $2 \%$ defined supplement (Kellogg et al., 1963) for 18 to $20 \mathrm{~h} \mathrm{a} 135{ }^{\circ} \mathrm{C}$ in an atmosphere of air plus $10 \%(\mathrm{v} / \mathrm{v})$ $\mathrm{CO}_{2}$ and enhanced humidity. The colonies were confirmed as gonococci by their oxidase and fermentation reactions and their typical bright fluorescence when treated with a specific antigonococcal conjugate (Difco). The gonococcal colonial types were selected using the special lighting system of Jephcott \& Reyn (I97I). Each of the selected types of all strains were grown in bulk on batches of 70 standard (90 mm) GC agar plates (Difco) and, after confirming that the gonococci were of the desired colonial type, the bacteria were harvested into $10 \mathrm{ml}$ deionized water in iron-free Universal containers. The organisms were washed once 


\section{Table I. Iron contents of different colonial types of Neisseria gonorrhoeae}

Results are expressed as $\mu \mathrm{g} \mathrm{Fe}$ (mg dry wt bacteria) ${ }^{-1}$.

$\begin{gathered}\text { Colonial } \\ \text { type }\end{gathered}$
1
2
3
4
5

\begin{tabular}{ccccc}
\multicolumn{5}{c}{ Strain } \\
F62 $^{*}$ & GC338 & GC41 & GCII3 & F62 (ANM)\$ \\
0.08 & 0.18 & 0.15 & NT & 0.17 \\
0.07 & 0.15 & 0.09 & NT & NT \\
0.14 & $0.29 \dagger$ & $0.15 \div$ & NT & NT \\
0.1 & 0.22 & 0.21 & 0.22 & 0.22 \\
NT & NT & NT & 0.15 & NT
\end{tabular}

NT, Not tested.

* International strain stored in liquid nitrogen.

$\uparrow$ Dull brown granulated variant with finely serrated edge.

* Very dark outer ring and smooth edge.

$\S$ Passaged several times in ANM.

by centrifuging at $3000 \mathrm{~g}$ and dried to constant weight in a high-vacuum freeze dryer (model EFO3; Edwards, Manor Royal, Crawley, Sussex).

Reagents for assay. Ashing fluid consisted of $\mathrm{H}_{2} \mathrm{SO}_{4}(98 \%, \mathrm{w} / \mathrm{w} ; 60 \mathrm{ml}), \mathrm{HClO}_{4}(72 \%, \mathrm{w} / \mathrm{v} ; 34 \mathrm{ml})$ and $\mathrm{VOSO}_{4}\left(0.25 \%, \mathrm{w} / \mathrm{v} ; 0.25 \mathrm{ml}\right.$ ). (The $\mathrm{VOSO}_{4}$ was dissolved in $100 \mathrm{ml}$ distilled water plus 6 drops of $98 \%$ $\mathrm{H}_{2} \mathrm{SO}_{4}$.) Chromogen was prepared immediately before use and consisted of sodium acetate ( $10 \%$, w/v; $15 \mathrm{ml}$ ), hydroxylammonium chloride $(2.5 \%, \mathrm{w} / \mathrm{v} ; \mathrm{I} 5 \mathrm{ml})$ and 4,7-diphenyl-I, IO-phenanthroline (bathophenanthroline) $(0 . \mathrm{I} \%, \mathrm{w} / \mathrm{v} ; 3.75 \mathrm{ml})$. [The bathophenanthroline was dissolved overnight in $70 \%(\mathrm{v} / \mathrm{v})$ ethanol.] Test standards were prepared from $\mathrm{FeSO}_{4} .7 \mathrm{H}_{2} \mathrm{O}$ in $0.5 \mathrm{M}^{-\mathrm{H}_{2}} \mathrm{SO}_{4}$.

Cleaning of all glassware. Extreme care was taken in all phases of the study to avoid metallic contamination from any source. All the glassware used for the iron assay was cleaned with detergent and water followed by soaking in $6 \mathrm{M}-\mathrm{HCl}$ (Analar), rinsing with either deionized or double-glass distilled water and drying in a hot-air oven on enamel dishes with the glassware covered with paper. All Pyrex glass tubes and pipettes were stored in a covered box to prevent contamination by dust. Such tubes and pipettes were then kept exclusively for iron assay.

Iron assay. The colorimetric technique of Seamer (1959) using bathophenanthroline was modified as follows: (i) $\mathrm{H}_{2} \mathrm{SO}_{4}$ and $\mathrm{HClO}_{4}$ were used for ashing instead of $\mathrm{HNO}_{3}$ and $\mathrm{HCl}$ which gave unacceptably high blanks due to traces of iron; (ii) ashing and colour development were carried out in a single Pyrex test-tube. These modifications increased the sensitivity of the assay to the microgram level.

Ashing fluid $(0.2 \mathrm{ml})$ was added to gonococci $[0.2$ to $0.4 \mathrm{ml}$ of a suspension (100 mg ml-1) of dried bacteria in distilled water] in a Pyrex test-tube containing three glass beads, $4 \mathrm{~mm}$ in diameter, and the mixture was heated carefully until clear. The ashed contents of the tubes were cooled and deionized water $(0.5 \mathrm{ml}), 18 \mathrm{M}-\mathrm{NH}_{4} \mathrm{OH}(0.3 \mathrm{ml})$ and alcoholic phenolphthalein $(0 . \mathrm{I} \% \mathrm{w} / \mathrm{v} ; 0.05 \mathrm{ml})$ were added followed by the dropwise addition of $5 \mathrm{M}-\mathrm{NH}_{4} \mathrm{OH}$ until the indicator was pink and then $0.5 \mathrm{M}-\mathrm{H}_{2} \mathrm{SO}_{4}$ until the solution was colourless. Chromogen $(2 \cdot 25 \mathrm{ml})$ was added and the mixture was boiled for 15 min for maximum colour development. The original assay of Seamer ( 1959 ) allows 10 to $20 \mathrm{~s}$ to decompose ferric pyrophosphate which is inadequate.

The colour was extracted into I-hexanol ( $\mathrm{I} .5 \mathrm{ml}$ ) with mixing for $4 \mathrm{~min}$ in a Vortex Junior mixer (Scientific Industries). The layers were separated by centrifuging, the top layer was transferred to a $\mathrm{I} \mathrm{cm}$ cuvette and the $E_{\tilde{5} 33}$ was determined. The iron content was then estimated from a standard curve.

Chemicals. Chemicals and reagents were analytical reagent grade quality from $\mathrm{BDH}$ or Koch-Light.

\section{RESULTS AND DISCUSSION}

The assay over seven separate experiments using $\mathrm{FeSO}_{4}$ standards was linear up to at least $5.59 \mu \mathrm{g} \mathrm{Fe}$ and was sensitive to $0.22 \mu \mathrm{g} \mathrm{Fe}$ which corresponded to a $\Delta E$ of 0.05 above a zero control. The mean value of $E_{533}$ and standard deviation (s.D.) at $5.59 \mu \mathrm{g} \mathrm{Fe}$ was $1.29 \pm 0.082$ with a standard error of the mean (S.E.M.) of $\pm 0.03 \mathrm{I}$; these S.D. and S.E.M. values were typical of those for other levels of iron.

The values obtained for the iron contents of gonococci (Table I) fell within the range of those quoted by Neilands (1974) for other species of bacteria. However, the iron contents of the pathogenic colonial types $I$ and 2 were lower than those of the relatively avirulent types 3 and 4 . Also the iron contents of types I, 2, 3 and 4 of stored F62 were lower but in 
similar proportion to one another as those of the colonial types of the freshly isolated strain GC338. The long storage in liquid nitrogen could have been responsible for this because after several passages in ANM the iron contents of types I and 2 of F62 (ANM) equalled those of the equivalent types of $\mathrm{GC}_{33} 8$.

Waring et al. (1953) demonstrated an increased pathogenicity for animals of Brucella suis rendered relatively iron-deficient in culture media compared with 'iron-normal' cultures of the same organism. They found iron-deficient Brucella suis was more invasive and produced a poorer inflammatory response in the host and suggested that the increased virulence was due to the host defence mechanism being more adversely affected by 'irondeficient' Brucella suis. Payne \& Finkelstein (1975) found that when relatively avirulent gonococci of colonial types 3 and 4 were inoculated along with iron into chick embryos their virulence increased, though iron had little or no effect on the virulence of types I and 2 in the same host. They suggested that iron might compensate for the absence of a virulence factor in types 3 and 4 by interfering with the chick embryo defence system. Recent observations in our laboratory suggest that the death of chick embryos injected intravenously with gonococci was not due to infection but to some form of endotoxic shock. Furthermore, there is ample evidence that in the course of experimental infection with Gram-negative organisms there is a release of endotoxins which bring about significant changes in the metabolism of iron by the host (Sussman, 1974). On the basis of our present observations, an increase in the critical environmental iron in the host might provide the necessary level of iron to express gonococcal virulence.

The authors thank Dr Pauline M. Harrison for her useful suggestions and advice during the course of the study. Dr T. O. Odugbemi is supported by a study leave grant from the University of Lagos.

\section{REFERENCES}

Brown, W. J. \& Kraus, J. (I974). Gonococcal colony types. Journal of the American Medical Association 228, 862-863.

Bullen, J. J., Rogers, N. J. \& Griffiths, E. (1974) Bacterial iron metabolism in infection and immunity. In Microbial Iron Metabolism, a Comprehensive Treatise, pp. 517--551. Edited by J. B. Neilands. London and New York: Academic Press.

Edwards, D. C. \& Seamer, P. A. (1960). The uptake of iron by Corynebacterium diphtheriae growing in submerged culture. Journal of General Microbiology 22, 705-7I 2.

Hafiz, S. \& McEntegart, M. G. (1976). Prolonged survival of Neisseria gonorrhoeae in a new liquid medium. British Journal of Venereal Diseases 52, $38 \mathrm{I}-383$.

JEPHCOTT, A. E. \& REYN, A. (197I). Neisseria gonorrhoeae. Colony variation I. Acta pathologica et microbiologica scandinavica B 79, 609-614.

Jephcott, A. E., Reyn, A. \& Birch-Andersen, A. (197I). Neisseria gonorrhoeae. III. Demonstration of presumed appendages to cells from different colony types. Acta pathologica et microbiologica scandinavica 79, 437-439.

Kellogg, D. S., Jr, Peacock, W. L., Jr, Deacon, W. E., Brown, L. \& Pirkle, C. I. (1963). Neisseria gonorrhoeae. I. Virulence genetically linked to clonal variation. Journal of Bacteriology 85, $1274^{-}$ 1279.

Kellogg, D. S., Jr, Cohen, I. R., Norins, L. C., Schroeter, A. L. \& Reising, G. (I968). Neisseria gonorrhoeae. II. Colonial variation and pathogenicity during 35 months in vitro. Journal of Bacteriology 96, 596-605.

NeIlands, J. B. (I974). Iron and its role in microbial physiology. In Microbial Iron Metabolism, a Comprehensive Treatise, pp. 3-34. Edited by J. B. Neilands. London and New York: Academic Press.

Payne, S. M. \& Finkelstein, R. A. (1975). Pathogenesis and immunology of experimental gonococcal infection. Role of iron in virulence. Infection and Immunity 12, I313-1318.

SEAmER, P. A. (1959). Estimation of $\mu \mathrm{gm}$. quantities of iron in culture medium, using bathophenanthroline. Nature, London $\mathbf{1 8 4}, 636-637$.

Sussman, M. (1974). Iron and infection. In Biochemistry and Medicine, pp. 650-679. Edited by A. Jacobs and M. Worwood. London and New York: Academic Press.

Swanson, J., Kraus, S. \& Gotschlich, E. C. (I97I). Studies on gonococcus infection. I. Pili and zones of adhesion; their relation to gonococcal growth patterns. Journal of Experimental Medicine 134, 886-906.

Walstad, D. L., Guymon, L. F. \& Sparling, P. F. (1977). Altered outer membrane protein in different colonial types of Neisseria gonorrhoeae. Journal of Bacteriology 129, I 623-1627.

Waring, W. A., Elberg, S. S., Schneider, P. \& GreEN, W. (I953). The role of iron in biology of Brucella suis. Journal of Bacteriology 66, 82-91. 